z Grudziądz vykazuje vysokú melodickú invenčnost' a že z jej vnútornej štruktúry môžeme vyčítat originálnu identitu jej tvorcu - autor bol básnik a zároveň aj skladatel' (hudobník), išlo teda o spojenie jeho poetických a muzikálnych schopností, ktoré zjednocoval duchovný princíp založený na konzervatívnejších tradíciách motetového princípu obdobia ars nova, neraz zasadených do úsmevných súvislostí (technikou paródie).

Vysoká profesionalita spracovanej problematiky predstavuje autora publikácie ako špecialistu nielen na stredovekú a renesančnú hudbu, ale aj ako historika, kulturológa, latinčinára a hudobného teoretika, pre ktorého je dôležitá hlbková analýza skúmaného javu. V knihe zúročil predchádzajúce muzikologické skúsenosti v oblasti výskumu dejín starých hudobných tlačí a výskumu kultúrnych dejín strednej Európy ako špecifického hudobného regiónu. Profesor Paweł Gancarczyk pôsobí v súčasnosti ako vedúci Oddelenia muzikológie v Umenovednom ústave Polskej akadémie vied (Instytut Sztuki
$P A N)$ vo Varšave, prednáša doma aj v zahraničí a je nositelom viacerých ocenení za svoju prácu (Prof. Hieronim Feicht Prize, Varšava 2001; Prix des Muses - Prix de l'Histoire, Paríž 2016). Je autorom knihy Musica scripto. Kodeksy menzuralne II połowy XV wieku na wschodzie Europy Łacińskiej (Warszawa : Instytut Sztuki Polskiej Akademii Nauk, 2001). Bol jedným z lídrov európskeho projektu HERA (Humanities in the European Research Area) Sound Memories: The Musical Past in Late-Medieval and Early-Modern Europe (2016 - 2019). Od roku 2019 je hlavným riešitel'om projektu Music in the Teutonic Order State in Prussia: Sources, Repertoires, Contexts a od roku 2020 je členom vedeckej spoločnosti Academia Europaea. Profesionálnu upútavku na knihu - sprevádzanú hudbou a tiež slovom samotného autora - môžu nájsţ záujemcovia na webovom portáli (<https://www.youtube.com/ watch? $\mathrm{v}=\mathrm{Q} 4 \mathrm{mPY} 2 \mathrm{TKZDQ}>$ ).

https://doi.org/10.31577/musicoslov.2021.2.4 Janka Petöczová

\title{
Janko Blaho: Záhorácké pjesňičky. Súborné vydanie
}

Ed. Peter Michalovič. Bratislava : Hudobné centrum v spolupráci so Záhorským múzeom v Skalici, 2018, 816 s. ISBN 978-80-89427-33-8

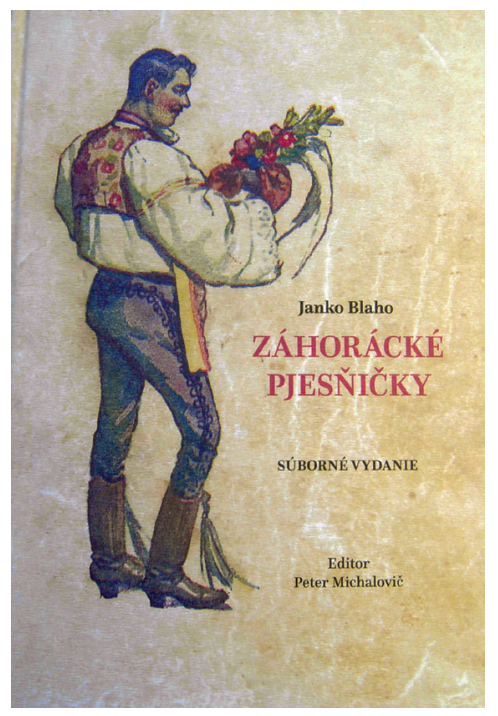

Dôležitou úlohou pri práci s historickými prameňmi ludových piesní je nielen ich uchovávanie v archívoch, múzeách a vedeckých inštitúciách, ale aj ich sprístupňovanie širšej verejnosti, editovanie, prípadne po čase aj nové vydanie. Najčastejšie ide o regionálne alebo lokálne piesňové zbierky, ktoré majú v praxi široké uplatnenie ako pramenno-kritické či popularizačné vydania. S týmto cielom pôvodne zbierali a vydávali svoje zápisy aj zberatelia - od profesionálnych bádatelov až po nadšencov, ktorí sa snažili najmä o zachytenie lokálneho repertoáru piesní $\mathrm{z}$ kraja, z ktorého pochádzali.

Z tohto dôvodu pôvodne vzniklo aj šest' dielov piesňovej zbierky zo zberatel'skej práce Janka Blaha (1901 - 1981), rodáka zo Skalice, jedného z prvých spevákov v opere Sloven- 
ského národného divadla $\mathrm{v}$ Bratislave. Jeho zberatel'ská práca bola motivovaná zálubou $\mathrm{v}$ regionálnej piesňovej tradícii. Z Blahovej zberatel'skej činnosti v rozsahu 1224 zapísaných piesní z 90 lokalít Záhoria boli postupne vydávané menšie piesňové zbierky $\mathrm{v}$ rozmedzí rokov: 1948, reed. 1954 (1. diel); 1952 (2. diel); 1956 (3. diel); 1970 (4. diel); 1975 (5. diel), pričom 6. diel (1986) bol vydaný až po zberatelovej smrti, na podnet jeho dcéry Heleny Jurasovovej-Blahovej. Svojím rozsiahlym záberom tvoria tieto zbierky jeden celok, ktorý predstavuje doteraz najhodnotnejší a najucelenejší korpus piesní zo Záhoria.

Neutíchajúci záujem o tieto zbierky a postupne aj ich nedostupnost' podnietili úsilie kompletne a monograficky ucelene sprístupnit tento piesňový materiál. Preto v spolupráci Hudobného centra v Bratislave so Záhorským múzeom v Skalici vznikla reprezentatívna monografická piesňová zbierka Záhorácké pjesňičky (2018) v editorskom spracovaní etnomuzikológa Petra Michaloviča v spolupráci s Vladimírom Godárom. Okrem editovania publikovaných piesňových zápisov Janka Blaha obsahuje aj mnohé dodatočné informácie priamo z pozostalostných zápisov zberatela a korektúry niektorých piesní v podobe pripojených strof $\mathrm{k}$ niektorým piesňam či komentáre alebo informácie $\mathrm{k}$ nim.

Pretože ide o prvé súborné vydanie všetkých piesní, ktoré Janko Blaho postupne zozbieral v období od 40. rokov do konca 70. rokov 20. storočia, na začiatku publikácie sú uvedené všetky úvody autora, ktoré napísal k pôvodným jednotlivým dielom piesňovej zbierky. Okrem krátkych informácií o vzniku zbierky takmer vo všetkých úvodoch poukazuje na problematiku zápisu záhoráckeho nárečia, ktoré sa výrazne mení aj podla jednotlivých obcí, pričom spomína aj okolnosti vzniku jednotlivých dielov piesňovej zbierky (napríklad väčší časový odstup medzi vydaním 4. a 5. dielu vysvetluje faktom, že pôvodne sám už nepredpokladal, že ešte zozbiera dalších vyše 200 piesní). V jednotlivých úvodoch svojich piesňových zbierok zberatel' v skratke opisuje prístup $\mathrm{k}$ zbieraniu a vysvetluje používanie (resp. zámeny) nárečových slov za „spisovnejšie“ pre prípad, ak by chceli piesne spievat aj speváci, ktorí nepochádzajú priamo zo Záhoria. Jazykovým poradcom Janka Blaha bol spisovatel' Ludo Zúbek, ktorý má v prvom diele piesňovej zbierky samostatný úvod, kde vysvetluje problematiku záhoráckeho nárečia. Pri novom vydaní kompletnej zbierky sa problematiky textových a nárečových korektúr ujala literárna historička a rodáčka zo Záhoria prof. Eva Fordinálová.

Výsledkom editorskej činnosti a využitia zbierok v Záhorskom múzeu v Skalici sú aj príspevky Janka Blaha zostavené do kapitoly s názvom "Za pesničkami na Záhorí. Zo zápisníka nár. umelca Janka Blahu“. Ide o sled kratších článkov, ktoré boli publikované v rozmedzí od mája do augusta 1981 v časopise Práca. Okrem humorných aj „osudových“ príhod, ktoré zberatel’ zažil pri stretnutí s konkrétnymi spevákmi, poukazuje aj na ich sociálny status (rolník, kováč, muzikant, učitel', mlynár), pričom v neposlednom rade hodnotí aj ich spevácke a hudobné kvality. Podobne ako Karol Plicka ani Janko Blaho spevákov nenahrával, nepoužíval zvukovú dokumentáciu, ale uprednostňoval priamy notový zápis $\mathrm{v}$ bezprostrednom kontakte so spevákom pri viacnásobnom predspievaní každej piesne.

$\mathrm{Z}$ odborného hladiska hodnotia túto zbierku komplexnejšie a v odlišných kontextoch dve štúdie: Slovo editora od P. Michaloviča a Vznik slovenskej národnej hudby a „záhorácké pjesňičky" od V. Godára. Štúdia editora sa zameriava najmä na historické kontexty záhoráckej ludovej piesne, jej pôvod a taktiež jej hudobno-teoretické zaradenie do etnomuzikologického kontextu. V neposlednom rade spomína viacerých spolupracovníkov Janka Blaha, ako bol maliar a grafik Martin Benka, učitel' Samuel Hatala či prof. Jozef Šátek, kňaz a pedagóg. Pri spolupráci so spevákmi zberatelovi významne pomáhal učitel' a organista Kornel Grešša, spevák, organista a zberatel' Florián Benkovič a rechtor-hudobník František Zemánek. Blahova zberatel'ská činnost’ inšpirovala viacerých hudobných skladatelov. Odborná štúdia redaktora publikácie V. Godára sa okrem historického kontextu slovenskej hudobnej tvorby podrobne zaoberá konkrétnymi piesňami zo zbierok Janka Blaha, 
ktoré inšpirovali nielen slovenských autorov, ale aj príslušníkov iných etník, napríklad Eugena Suchoňa, Zdenka Mikulu, Tibora Andrašovana, Rudolfa Macudzińského, Štefana Németha-Šamorínskeho, Vítězslava Nováka či Zdenka Folprechta. Okrem jednoduchších aj náročnejších úprav pre spev a klavír sa mnohé piesne stali predlohou aj orchestrálnych a zborových skladieb.

Samotný korpus publikácie tvorí súhrn 1224 piesní, ktoré boli nanovo abecedne usporiadané zo všetkých 6 piesňových zbierok Janka Blaha, podobne ako ich abecedne zoradil $\mathrm{v}$ jednotlivých dieloch pôvodného vydania aj samotný zberatel'. Spôsob publikovania jednotlivých piesní zachováva pôvodnú koncepciu zbierok - t. j. pri všetkých piesňach je okrem textového incipitu $\mathrm{v}$ nadpise uvedené meno speváka a názov lokality, v ktorej bola pieseň zaznamenaná. Pri každej piesni je uvedený aj spôsob prednesu či prednesový pokyn (náladove, tahavo, pomaly, volne, mierne, baladicky a pod.). Čo sa týka žánrového a druhového zaradenia jednotlivých piesní, bolo vo vel'kej miere doplnené až v novej edícii, pričom rozlišuje údaje pochádzajúce od samotného zberatela a údaj dodaný editorom.

Publikácia obsahuje registre a súpisy, potrebné pri orientácii $\mathrm{v}$ zbierke a pri práci $\mathrm{s}$ piesňovými zápismi. Patrí $\mathrm{k}$ nim slovníček nárečových slov, výrazov zo Záhoria, ktorý spracoval sám zberatel’ a pri súčasnej edícii prešiel iba minimálnou gramatickou úpravou. Ďalej bol vypracovaný podrobný register abecedne zoradených piesní, ktorý zahŕňa informácie o poradovom čísle piesne, lokalite, spevákovi, spolu so žánrovou charakteristikou, ktorá pri prvých vydaniach bola určená iba sporadicky. Súčastou príloh je mapa Záhoria s lokalitami, v ktorých Janko Blaho zbieral, abecedný zoznam obcí a samostatný register žánrového určenia piesní. Zbierku dopIńajú fotografie zberatela a jeho rodinných príslušníkov, najbližších spolupracovníkov a vybraných spevákov a speváčok.

Na záver je potrebné vyzdvihnút, že ide o mimoriadne kvalitne pripravenú publikáciu pramenno-kritického zamerania. Jej vydanie bolo nepochybne velmi potrebné po viac ako 30 rokoch od vydania posledného dielu tejto piesňovej zbierky v jej prvom vydaní. Táto rozsiahla piesňová zbierka spíňa všetky odborné kritériá. Sprostredkúva kvalifikovaným spôsobom širšej verejnosti a nadšeným záujemcom o ludovú pieseň materiál, vhodný nielen na interpretáciu, ale aj na kompozičné spracovanie. Týmto spôsobom piesňová zbierka zapĺn̆a výraznú vydavatel'skú medzeru, pričom v nemalej miere napína popularizačný ciel' - šírenie a zachovávanie historického repertoáru záhoráckych ludových piesní.

https://doi.org/10.31577/musicoslov.2021.2.5 Miriam Timková 